\title{
Legal regulation of corporate governance in state agricultural companies in Russia
}

\author{
Alexander Yakovlev ${ }^{1,2, *}$ \\ ${ }^{1}$ Diplomatic Academy of the Ministry of Foreign Affairs of the Russian Federation, International and \\ National Security Department, 119034 Moscow, Russia \\ ${ }^{2}$ State University of Management, State and Municipal Management Department, 109542 Moscow, \\ Russia
}

\begin{abstract}
The article considers legal aspects of corporate governance in an important sector of the Russian economy - agriculture. The author concentrates his attention on state companies. Today there are much less state agricultural companies then 10 or even 5 years earlier. The most famous are JSC "Rosagroleasing", JSC "United grain company" and JSC "Head center for reproduction of agricultural animals". The biggest state agricultural companies are in federal property. Russian regions are owners of agricultural companies too. Every owner (the Russian Federation or Russian regions) establishes its own rules for the functioning of companies. Some regions have special regional laws on governing state companies. Others adopted government resolutions. There is a big difference between legal regulation on corporate governance in state and private agricultural companies in Russia. Sate companies are highly regulated by different kind of legal acts.
\end{abstract}

\section{Introduction}

Agriculture throughout the history of the country has been one of the most important sectors of the Russian economy. In addition to creating jobs, paying taxes and other payments it provides the population with food. Their quality affects the health of residents. Their availability and accessibility affects food security and independence of the Russian Federation.

The state plays a significant role in the Russian economy. It is represented in all key industries. On the one hand the state acts as a regulator, on the other hand it participates in the economy through legal entities the founder and owner of which it is. Different organizational and legal forms are used. Among them are budgetary, official order and autonomous institutions [1-2], unitary enterprises, joint-stock and limited liability companies [3-5].

In agriculture there are almost all mentioned organizational and legal forms. We can find a certain number of joint-stock companies. Some of them are well known. For example: JSC "United grain company", JSC "Rosagroleasing", JSC "Russian hippodromes", JSC "Head center for reproduction of agricultural animals", JSC "Foreign

\footnotetext{
* Corresponding author: gosypravlenie@yandex.ru
} 
economic corporation "Prodintorg". There are no public joint-stock companies with state participation.

\section{Research materials and methods}

The subject of our research does not often have reflection in scientific works of Russian authors. More often is possible to find articles related to different problems of management [6-9], economics [10-13] and law [14-17]. There are also some works on the theme of agricultural market in Russia [18-20].

One of the reasons why Russian state companies do not often become a subject of a study is the existing amount of them.

In this research by the category "state agricultural company" we mean joint-stock company or limited liability company with the participation of the Russian Federation or a region.

In Russia there is a decreasing trend in number of state companies. We can clearly see it on the example of federal companies (Fig. 1).

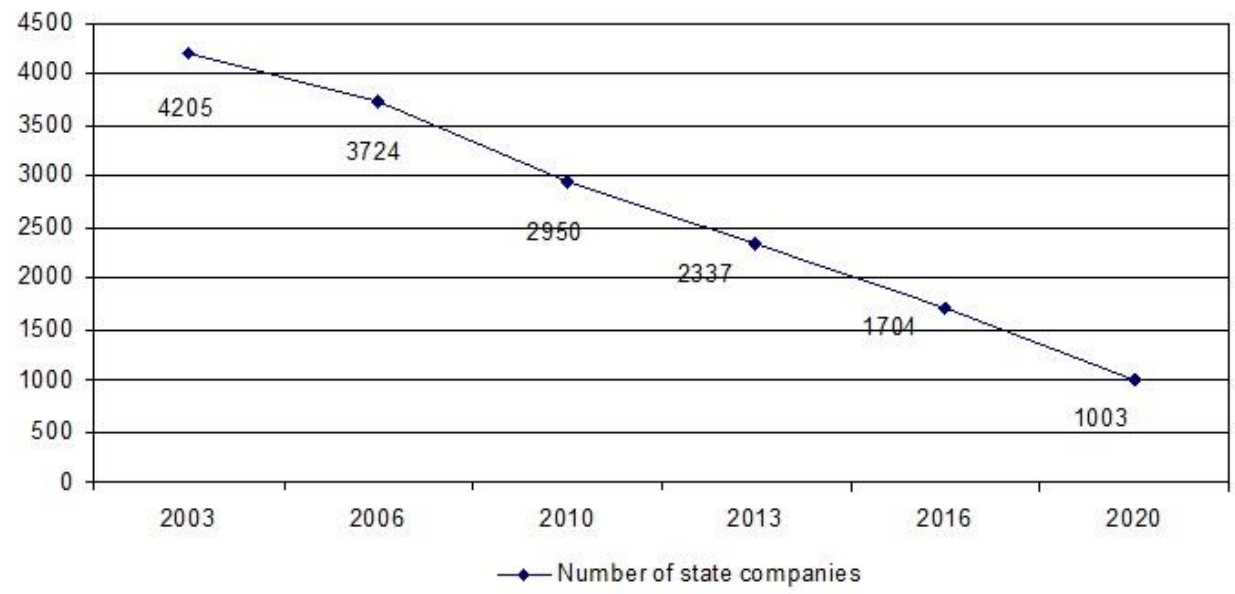

Fig. 1. Number of state companies with the Russian Federation's participation in 2003-2020

Over the past 17 years the number of companies has decreased by more than 4 times from 4205 companies in 2003 to 1003 companies in January 2020. Today there are less than a thousand federal state companies.

It's interesting to define the proportion of agricultural companies in the total mass of state companies with the Russian Federation's participation. Unfortunately there is no try official information about the number of state agricultural companies. If we carry out an independent classification of companies by industry and single out agricultural companies we get the following. Today the proportion of agricultural companies in federal property is about $3 \%$.

Also there are about near 2000 companies with regional participation in Russia. The number and proportion of agricultural companies differs. For example, in Tyumen region $20 \%$ of state companies are agrarian. In Yaroslavl region there are 3 state agricultural companies (OJSC "Yaroslavlagropromtekhsnab", OJSC "Greenhouse complex "Tunoshna" and OJSC "Yaroslavl bakery №4") or about 17\%. Near mentioned percentage of state agricultural companies is in Pskov region. But there is only 1 economic entity in agricultural sphere - LLC "Pskov fishing complex Zalita". 
These facts show that agricultural companies are presented in different parts of Russia and play a significant role in Russian economy. It makes the study on the stated topic relevant.

The author in current research used a methodology based on general scientific methods. Among them: induction, deduction, analysis, synthesis, comparison, etc. The author also applied to retrospective methods.

\section{Research results}

In the Russian Federation on the federal level there is no special law on the issue of governing state companies. But there are laws which regulate a number of areas of our interest.

There are the following existing acts (Table 1).

Table 1. Acts on governing state agricultural companies

\begin{tabular}{|c|c|}
\hline Mandatory & Optional \\
\hline - Civil Code of the Russian Federation; & \\
- Tax Code of the Russian Federation; & \\
- The Federal law "On joint-stock & \\
companies"; & \\
- The Federal law "On limited liability & \\
companies"; & \\
- The Federal law "On the procurement of \\
goods, works, services by certain types of \\
legal entities"; \\
- The Federal law "On accounting"; \\
- The Federal law "On the privatization of \\
state and municipal property"; \\
- The Federal law "On Insolvency \\
(Bankruptcy)"; \\
- The Federal law "On audit activity"; \\
- The Federal law "On protection of \\
competition"; \\
- Regulation on the management of federally \\
owned shares of joint-stock companies... \\
[21]; \\
- decisions of the Government of the \\
Russian Federation (for example "On the \\
specifics of disclosure..." [22]); \\
- acts of authorities of the Russian \\
Federation and Russian regions; \\
- regional laws; \\
- instructions on privatization conditions; \\
- directives; \\
- local acts
\end{tabular}

As we can see some of them are binding. The other one are non-binding. The most important are Civil Code of the Russian Federation, federal laws "On joint-stock companies" and "On limited liability companies".

Besides federal acts a big number of regional laws or decrees exist in the country. Some regions have several documents. Moscow city (a city of federal importance) is an example of that. 
Today there is no special act on governing state agricultural companies or even private agricultural companies.

Table 2. Local acts on governing state agricultural companies

\begin{tabular}{|c|c|}
\hline Act & Adopted \\
\hline Chapter & General meeting of shareholders (owners) \\
\hline $\begin{array}{l}\text { Regulation on the general shareholders } \\
\text { meeting }\end{array}$ & General meeting of shareholders (owners) \\
\hline Regulation on the board of directors & General meeting of shareholders (owners) \\
\hline Regulation on the revision commission & General meeting of shareholders (owners) \\
\hline Regulations on committees & Board of directors \\
\hline $\begin{array}{l}\text { Regulation on the remuneration of the } \\
\text { members of the board of directors }\end{array}$ & General meeting of shareholders (owners) \\
\hline $\begin{array}{l}\text { Regulation on the remuneration of the } \\
\text { members of the revision commission }\end{array}$ & General meeting of shareholders (owners) \\
\hline Regulations on the single executive body & General meeting of shareholders (owners) \\
\hline $\begin{array}{l}\text { Regulations on the remuneration of the } \\
\text { single executive body }\end{array}$ & $\begin{array}{l}\text { General meeting of shareholders (owners) or } \\
\text { board of directors }\end{array}$ \\
\hline Development strategy & Board of directors \\
\hline Regulations on the KPIs & Board of directors \\
\hline Regulations on the procurement & Board of directors \\
\hline Directives & Responsible authorities \\
\hline
\end{tabular}

As we can see the most important local act are adopted by general meetings.

\section{Conclusion}

The author based on carried out analysis of acts on governing state agricultural companies came to the following conclusions.

There are significant differences between state and private agricultural companies in the field of corporate governance in Russia.

The mane differences are the following.

Federal and regional companies are highly regulated by different acts. A lot of them exist only in state companies. The example is a category of local documents called 
"directives". They prescribe what actions state representatives must take. In particular, how to vote on a meeting of a board of directors.

Despite a high degree of regulation of corporate governance in state agricultural companies they continue to work quite effectively and often gain new markets for their products.

\section{References}

1. I.I. Kokhanovskaya, Y.V. Nazarenko, Upravlenie, 2, 4-9 (2018)

2. I.V. Chebotnikov, A.Y. Yakovlev, I.V. Glazunova, Legal support of management and financial control over the activities of state budgetary institutions of the city of Moscow (Moscow, Publishing House of the Moscow University for the Humanities, 2019)

3. D.A. Zhmulina, O.A. Makarova, Bulletin of St. Petersburg University. Law, 2, 32-47 (2014)

4. A.Y. Yakovlev, The European Proceedings of Social \& Behavioural Sciences, 76, 3376-3382 (2019)

5. Corporate management level. Informational and educational portal in state and municipal management, Retrieved from: http://gimyrf.ru/corporativnyj_uroven/ (2020)

6. V.G. Antonov, V.V. Maslennikov, Bulletin of the University, 6, 13-22 (2014)

7. A. Borovikov, O. Smolyakov, Upravlenie, 7(3), 54-62 (2019)

8. G. Butkovskaya, E. Sumarokova, E-Management, 2(3), 48-57 (2019)

9. O.B. Kozhevina, Upravlenie, 8(1), 141-149 (2020)

10. E.B. Lenchuk, Studies on Russ. Econ. Development, 27(3), 332-340 (2016)

11. V.S. Osipov, I.I. Smotritskaya, Public service and personnel, 2, 165-169 (2016)

12. A.E. Gorodetsky, Scientific works of the Free Economic Society of Russia, 2, 279-310 (2017)

13. I.I. Smotritskaya, S.S. Shuvalov, Econ. and Soc. Changes: Facts, Trends, Forecast, 10(5), 99-114 (2017)

14. I.V. Glazunova, Siberian Legal Review, 16(4), 512-517 (2019)

15. V.V. Dolinskaya, Laws of Russia: experience, analysis, practice, 3, 3-14 (2018)

16. R.D. Grebnev, The Social Science, 11(22), 5309-5313 (2016)

17. O.V. Gladysheva, V.A. Sementsov, Legal Concept, 2, 17-25 (2018)

18. I.M. Kulikov, I.A.Minakov, Scientific papers. Series: management, economic engineering and rural development, 19(4), 141-147 (2019)

19. A. Yakovlev, V. Mikhaylov, E3S Web of conferences, 176, 05022 (2020)

20. I.A. Minakov, A.V. Nikitin, International journal of innovative technology and exploring engineering, 9(1), 3842-3847 (2019)

21. Regulation on the management of federally owned shares of joint-stock companies and the use of the special right to participate of the Russian Federation in the management of joint-stock companies ("golden share"). Approved by the decision of the Government of the Russian Federation dated 03.12.2004 № 738.

22. Decision of the Government of the Russian Federation of 04.04.2019 № 400 "On the specifics of disclosure and provision of information subject to disclosure and provision in accordance with the requirements of the Federal Law "On Joint-Stock Companies "and the Federal Law" on the securities market". 
23. Corporate governance code. Recommended by the letter of the Bank of Russia of 10.04.2014 № 06-52/2463 "On the Corporate governance code". 